\title{
HYGIENE ASSESSMENTS OF SCHOOL KITCHENS BASED ON THE MICROBIOLOGICAL STATUS OF SERVED FOOD
}

\author{
András J. Tóth ${ }^{1,2}$, Katalin Szakmár ${ }^{3}$, Anna Dunay², Csaba B. Illés ${ }^{2 凶}$, \\ András Bittsánszky ${ }^{1}$ \\ ${ }^{1}$ InDeRe Institute for Food System Research and Innovation Nonprofit Ltd. \\ Fehérvári út. 132-144, H-1116 Budapest, Hungary \\ 2Department of Business Economics and Management, Szent István University \\ Páter K. u. 1, H-2100 Gödöllö, Hungary \\ ${ }^{3}$ Department of Food Hygiene, University of Veterinary Medicine \\ István u. 2, H-1078 Budapest, Hungary
}

\begin{abstract}
Background. According to European trends, more children eat at school canteens than ever before, therefore food safety and quality have become increasingly significant in recent years. Nevertheless, there are large differences in food safety levels in different school canteens. We hypothesize that the microbial status of the served meal represents on the general hygiene of the kitchen. Our research examines whether mesophilic aerobic bacteria measured in served food are connected with the level of hygiene in the catering unit, and whether this indicator can be used as a criterion for assessing school kitchens.

Material and methods. Meal samples were collected from six school kitchens, and mesophilic aerobic bacterial count was measured. Samples were collected on five different days, so each kitchen was monitored five times. Two meals per visit were collected: a soup and a main course.

Results. Out of the 60 samples, 26 were $\operatorname{good}\left(\mathrm{CFU} / \mathrm{g}<10^{3}\right), 24$ were acceptable $\left(\mathrm{CFU} / \mathrm{g}: 10^{3}-10^{5}\right)$, and in 10 samples, the microbial count was found to be above the limit $\left(\mathrm{CFU} / \mathrm{g}>10^{5}\right)$. Statistical calculations revealed that microbial contamination of served meals was influenced neither by the supplier nor by the type of meal (soup or main course). However, the level of hygiene in the serving kitchen significantly affects the microbial status of meals.

Conclusion. Based on the results, a qualification system can be developed using the mesophilic aerobic bacterial count measurable in the served meal to assess hygiene. By regular determination of mesophilic aerobic bacterial count and the presence of Enterobacteriaceae, the food safety of a catering unit can be quantitatively evaluated.
\end{abstract}

Keywords: microbiological quality, school food, microbial food safety, quality assurance, rapid microbiology, contract catering

A. J. Tóth was supported by New National Program for Excellence by the Hungarian Ministry of Human Capacities - UNKP$-17-3$.

『illes.b.csaba@gtk.szie.hu 
Tóth, A. J., Szakmár, K., Dunay, A., Illés, C. B., Bittsánszky, A. (2018). Hygiene assessments of school kitchens based on the microbiological status of served food. Acta Sci. Pol. Technol. Aliment., 17(2), 159-168. http://dx.doi.org/10.17306/J.AFS.2018.0564

\section{INTRODUCTION}

Nowadays, more and more attention is being paid to the contract catering sector, including children's catering, all over the world (Bonell et al., 2013; Cohen et al., 2012; 2014; Vieux et al., 2013). It is generally recognized that the quality of consumed food has a remarkable influence on public health. Nowadays, it is becoming common for children to consume at least one main meal per day outside of the home, most frequently at school canteens. Therefore, getting safe, good quality food is a basic demand in these institutions, which can primarily be established by means of quality assurance (Garayoa et al., 2014).

The hygiene of heat-treated food should be appropriate. For preserving food quality, the processes from preparation to serving must be carried out professionally. According to our hypothesis, any failure occurring between the time of preparation and the time of serving affects the microbial status of the food, which can be determined by various measurement methods.

The standard microbiological testing methods are time consuming, and days may elapse before results can be obtained. Preventive microbial tests are included in HACCP plans but further measurements are carried out when a food-borne disease outbreak is detected. Unfortunately, when the problem has occurred, result may take 3-5 days to arrive, which can be worrying and even dangerous. Therefore, it is more practical to use quicker testing methods at the end of the food preparation chain, directly before consumption of the food. The introduction of rapid microbiological testing methods into the final step of quality control can promptly indicate defective products. Furthermore, it can determine whether or not a unit ensures appropriate hygienic conditions during its activity. In our present work, besides conventional methods, the MicroTester instrument (Erdősi et al., 2012; Reichart et al., 2007), which indicates the growth of bacteria through a change in redox potential, was used.

The redox potential is a complex indicator of the physiological state of microbes, and it can be used for the qualitative and quantitative determination of the microbial load (Brasca et al., 2007; Ignatova et al., 2010; Tachon et al., 2010). Bacterial growth decreases the redox potential of the medium. The shape of the redox curve is based on the type of microorganisms.
The principle of the MicroTester method is that during the microbial multiplication, the redox potential of the medium is identifiably reduced. The time to detection (TTD) refers to the time required for the redox potential change to overcome the detection criterion (DC). DC is a prescribed value which is significantly different from random changes. There is a close linear correlation between TTD and the logarithm of the initial viable count (Reichart et al., 2007). The change in redox potential is independent of the shape and size of the test cell and the composition of the nutrient medium. Therefore, the measurements can be carried out with any sample size in any liquid nutrient medium. Correspondingly, the MicroTester instrument enables the use of culture media for the standard microbiological processes as well. The shape of the redox curve is related to different microbial groups that differ from one another; by this means, in certain cases, the method makes it possible for the rough identification of the microbial group (Erdősi et al., 2012).

In a previous work, 68 school kitchens were surveyed for hygienic adequacy (Tóth and Bittsánszky, 2014). The survey was carried out in accordance with hygiene regulations, and on this basis, the kitchens were ranked into three groups: good (hygienic sanitary score of $76 \%$ or more), acceptable (60-76\%) or unacceptable (below $60 \%$ ) food safety and hygiene levels. In the present study, it was investigated whether the mesophilic aerobic bacterial count measurable in the served meals is connected with the hygiene classification of the kitchens, that is, whether it is possible to draw conclusions about hygiene in the kitchen from the microbiological status of the served meal.

According to the Commission Regulation (EC) No $2073 / 2005$, process hygiene criteria are used to indicate the correct functioning of the production process. In contrast, food safety criteria define the acceptability of a product on the market. In this work, we focus solely on process hygiene criteria.

For the characterization of the microbial status and the mesophilic aerobic, bacterial count was used as an indicator. Mesophilic aerobic bacteria can be used as indicators for the determination of the shelf life and spoilage status of food, and they are also useful in evaluating the sanitary condition of food (Bibek and Bhunia, 2004; Jay et al., 2005). 
Tóth, A. J., Szakmár, K., Dunay, A., Illés, C. B., Bittsánszky, A. (2018). Hygiene assessments of school kitchens based on the microbiological status of served food. Acta Sci. Pol. Technol. Aliment., 17(2), 159-168. http://dx.doi.org/10.17306/J.AFS.2018.0564

We also examined the presence of the Enterobacteriaceae family in the food. Enterobacteriaceae are commonly used as indicator organisms in processed food, particularly in heat-treated food. Depending on the initial contamination level and treatment, they can provide a reliable indication of process inadequacy, under-processing or cross contamination. With certain foods, Enterobacteriaceae can also measure the quality of food and spoilage potential. The Enterobacteriaceae family is used for monitoring sanitation in food processing plants (Tortorello, 2003) and may be useful indicators of overall good manufacturing practice (Baylis et al., 2011).

\section{MATERIALS AND METHODS}

\section{Sample collection}

The survey was carried out at the mass catering establishments of six secondary schools in Budapest, Hungary. The HACCP system was introduced and used in all of these kitchens. In these units $60-90$ people (students and teachers) are served daily. Meals were not prepared in the kitchens and were delivered from external cooking units in isothermal containers. On the sampling days, the menu was exactly the same in all six kitchens; however, the meals were provided by two different suppliers. Each supplier supplied three kitchens. The kitchens investigated in the present survey were assessed in terms of hygiene in an earlier study (Tóth and Bittsánszky, 2014). In this work, kitchens were ranked following a checklist-based assessment. The checklist contained 223 examination points and was developed according to legislations and regulations concerning the hygienic and sanitary conditions of kitchens. This classification was based on the assessment of the physical layout and environment of the kitchen, procedures followed by kitchen staff, adequacy of equipment and utensils, adequacy of food delivery and storage, food preparation, serving and cleaning, quality assurance and conditions in the dining hall. Two kitchens were qualified as good in terms of hygienic and sanitary conditions, two of them were acceptable, and two were classed as unacceptable. A summary information related to sampling sites is shown in Table 1.

The six sites for sample collection were visited at the same time. Kitchen staff were not informed in
Table 1. Features of the school kitchens where the samples were collected. A hygiene assessment of these kitchen was performed earlier (Tóth and Bittsánszky, 2014)

\begin{tabular}{ccc}
\hline Kitchen no. & Hygienic qualification result & Food supplier \\
\hline 1 & good $(82 \%)$ & A \\
2 & good $(80 \%)$ & B \\
3 & acceptable (71\%) & A \\
4 & acceptable (66\%) & B \\
5 & not acceptable (49\%) & A \\
6 & not acceptable $(54 \%)$ & B \\
\hline
\end{tabular}

advance about the sample collection. At the kitchens (they have a self-service system), samples of the meals that were being served were collected and then placed into sterile boxes, using the utensils available at the kitchen. If the meal had to be cut into smaller pieces for consuming (e.g. steak, cutlet), it was done on the spot using the utensils provided by the canteen. Meals that consisted of more components (e.g. meat with garnish) were mixed. The samples drawn from the meals were delivered immediately to the laboratory, where microbiological investigations were carried out immediately. Delivery of the samples to the laboratory took 20-35 minutes. Food samples were transported in a Thermobox at $37^{\circ} \mathrm{C}$. The origin of the samples was not indicated on the boxes; laboratory personnel had no preliminary information about the samples that could influence the final results.

Samples were collected on five different days, so each kitchen was monitored five times. The meal on each day consisted of a soup and a main course. The meals are listed in Table 2.

The meals were entirely heat treated, and further processing was not required. Following the delivery procedures, hot holding and serving were carried out. The only exception was the main dish $\mathrm{M}_{4}$, which consisted of a cooked noodle dish served with a non-heattreated sweet spread (poppy-seed or walnut mixed with powdered sugar). 
Tóth, A. J., Szakmár, K., Dunay, A., Illés, C. B., Bittsánszky, A. (2018). Hygiene assessments of school kitchens based on the microbiological status of served food. Acta Sci. Pol. Technol. Aliment., 17(2), 159-168. http://dx.doi.org/10.17306/J.AFS.2018.0564

Table 2. Soups (S) and main dishes (M) analysed

\begin{tabular}{cll}
\hline Sampling days & \multicolumn{1}{c}{ Soups } & \multicolumn{1}{c}{ Main dishes } \\
\hline Day 1 & S1: broth with small flat noodles & M1: beef stew in brown sauce with spaghetti \\
Day 2 & S2: semolina dumpling soup & M2: cabbage cooked with tomato sauce and pork cutlet \\
Day 3 & S3: green bean soup & M3: roasted chicken leg with rice \\
Day 4 & S4: pork ragout soup (with vegetables) & $\begin{array}{l}\text { M4: sweet noodles (cooked noodles with poppy-seed } \\
\text { or walnut mixed with powdered sugar) }\end{array}$ \\
Day 5 & S5: vegetable soup & M5: pork stew made with vegetables and rice \\
\hline
\end{tabular}

\section{Detection of mesophilic aerobic bacterial count}

Determination of mesophilic aerobic bacterial count measurable in ready-to-eat meals was carried out by conventional plating methods (according to ISO 4833:2003 standard) and by means of MicroTester equipment, based on the measurement of redox potential (Reichart et al., 2007). During the MicroTester investigation, a $10 \mathrm{~g}$ sample of the meal was suspended in $90 \mathrm{ml}$ saline pepton solution using Stomacher apparatus, and $1 \mathrm{ml}$ of the suspension was transferred into $9 \mathrm{ml}$ of half strength TSB (Tryptic Soy Broth) culture medium. The time to detection (TTD) was measured at $30^{\circ} \mathrm{C}$. The determination of bacterial count was carried out by MicroTester, a 32-channel redox potential measuring instrument. The MicroTester system consisted of: water bath thermostat (accuracy: $\pm 0.2^{\circ} \mathrm{C}$ ), test cells - which, in this case, were $30 \mathrm{ml}$ measuring cells equipped with Schott Blue Line 31 RX redoxelectrodes - PC drive (Windows 7, special software) and a data collection and evaluating unit. All the measurements were performed on two parallel analyses of samples. All the media used for this research were purchased from MERCK Hungary. To summarize, each of the six kitchens were visited five times. Two meal types (soup and main course) were sampled during each visit. Overall, 60 measurements were performed with plate counting methods and 60 using the MicroTester method. All microbiological measurements were performed in triplicate.

\section{Preparation of calibration curves}

An external calibration curve was created for the determination of bacterial count from TTD values. For this purpose, tenfold dilution series were prepared from the cultures of each investigated meal, and the microbial count $(\mathrm{N})$ in each dilution was determined by the plate counting method (ISO 4833:2003) and by using MicroTester apparatus. TTD values for each dilution were determined using half-strength TSB (MERCK 146599) culture broth. Calibration curves were plotted based on the $\log \mathrm{N}$ values, determined by the standard method and the TTD values measured by the MicroTester apparatus.

The sensitivity of the method can be calculated based on the slopes of the calibration curves. Previous results showed that a one-logarithm unit increase in the initial cell concentration decreased the TTD values by $68-132 \mathrm{~min}$, depending on the microorganisms and food matrices tested (Reichart et al., 2007). The repeatability and reproducibility (Erdősi et al., 2012) of the experiment comply with the requirements for microbiological methods.

\section{Detection of Enterobacteriaceae}

Another advantage of the MicroTester is that due to the different shapes of their redox curves, the presence of Enterobacteriaceae can be determined simultaneously by applying non-selective nutrient broth (TSB) in a single, common measurement system. From the bacteria usually found in the food industry, only Enterobacteriaceae reduce the redox potential below $-300 \mathrm{mV}$ in the aerobic culture media used for redox potential measurements (Erdősi et al., 2012). Thus the presence of Enterobacteriaceae was evident when the redox potential was reduced below $-300 \mathrm{mV}$.

\section{Statistics}

Comparison of results obtained by the MicroTester and plate counting method was carried out by applying linear regression. Data was evaluated using 
Tóth, A. J., Szakmár, K., Dunay, A., Illés, C. B., Bittsánszky, A. (2018). Hygiene assessments of school kitchens based on the microbiological status of served food. Acta Sci. Pol. Technol. Aliment., 17(2), 159-168. http://dx.doi.org/10.17306/J.AFS.2018.0564

Student's t-test, ANOVA and Duncan's multiple range test methods $(p<0.05)$. Microsoft Excel and IBM SPSS for Windows software packages were used for calculations.

\section{RESULTS AND DISCUSSION}

\section{Preparation of calibration curves}

Altogether, 15 kinds of meals were used for preparing calibration curves (data not shown). Calibration curves were determined by plotting the logarithm of microbial counts $(\log \mathrm{N})$ against detection time (TTD). The lowest value significantly different from random changes $(-0.4 \mathrm{mV} / \mathrm{min})$ was established as the detection criterion in each case. As has been stated, there was no common calibration curve applicable to all the samples. Further, the food samples were divided into six groups, and the calibration curves were determined within each group. For comparison, calibration curves are collectively shown and summarized in Figure 1.
Based on data shown in Figure 1, it can be stated that - although a common calibration curve cannot be applied to the investigated ready-to-eat meals - if the detection time is less than 3 hours, all the food groups can be considered heavily contaminated, as the microbial concentration is above $10^{-6} / \mathrm{g}$ in all samples.

\section{Results related to the mesophilic aerobic bacterial counts measurable in food samples}

Microbial sample analyses were carried out using the MicroTester instrument and by the conventional plate counting method (ISO 4833:2003). The correlation coefficient between the two methods was 0.9626 and slope was $1.049 x \pm 0.02714$, showing high correlation (Fig. 2).

Meal samples were categorized into three groups (good, acceptable and unacceptable) according to mesophilic aerobic bacterial counts, according the criteria of United Kingdom's Health Protection Agency (Health..., 2009). The results of the classification are presented in Table 3. The microbial status of meals

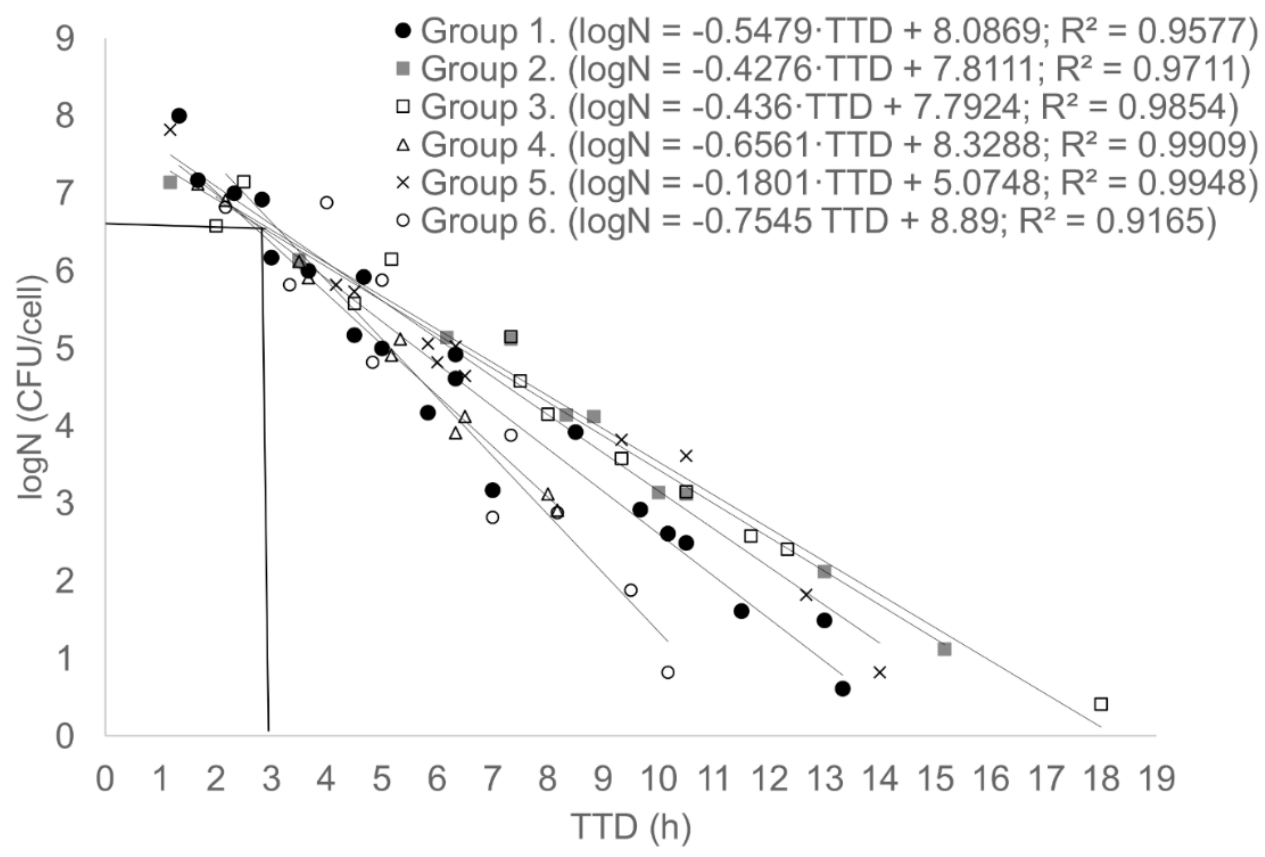

Fig. 1. Calibration curves for groups of meals: group 1 - soups, group 2 - meals made of or containing noodles, group 3 - meals containing pork, group 4 - meals containing fish or chicken, group 5 - meals made with tomato, group 6 - sweet noodles 
Tóth, A. J., Szakmár, K., Dunay, A., Illés, C. B., Bittsánszky, A. (2018). Hygiene assessments of school kitchens based on the microbiological status of served food. Acta Sci. Pol. Technol. Aliment., 17(2), 159-168. http://dx.doi.org/10.17306/J.AFS.2018.0564

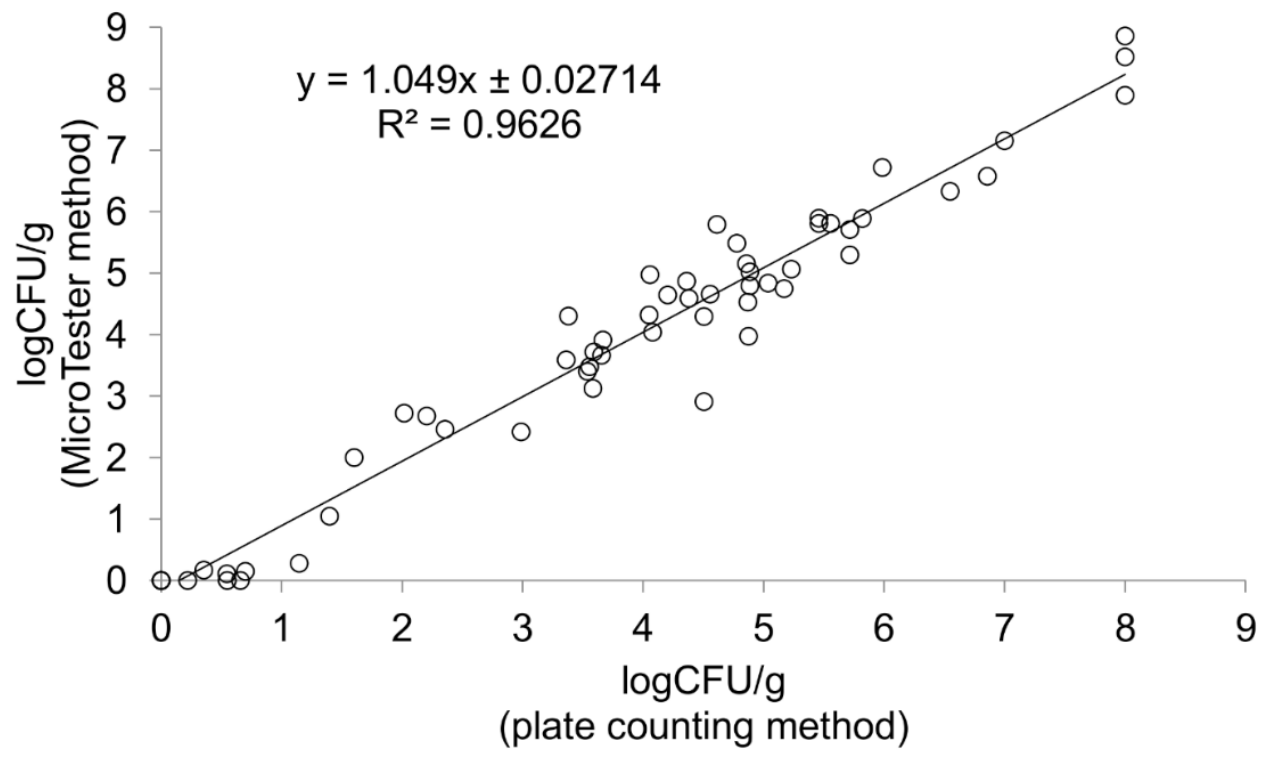

Fig. 2. Comparison of standard plate counting method and MicroTester method by linear regres$\operatorname{sion}(n=60)$

Table 3. Distribution of meals served at school kitchens (number of meals $=60$ ) according to their adequacy based on mesophilic aerobic bacterial count measurable by MicroTester (criteria of Health Protection Agency of United Kingdom, 2009)

\begin{tabular}{cccc}
\hline Kitchen no. & $\begin{array}{c}\text { Good } \\
\left(\mathrm{CFU} / \mathrm{g}<10^{3}\right)\end{array}$ & $\begin{array}{c}(\mathrm{CFU} / \mathrm{g} \\
\left.10^{3}-10^{5}\right)\end{array}$ & $\begin{array}{c}\text { Unacceptable } \\
\left(\mathrm{CFU} / \mathrm{g}>10^{5}\right)\end{array}$ \\
\hline 1 & 6 & 4 & 0 \\
2 & 6 & 4 & 0 \\
3 & 3 & 3 & 4 \\
5 & 2 & 6 & 2 \\
6 & 2 & 2 & 6 \\
\hline Total & 22 & 2 & 5 \\
\hline
\end{tabular}

served from kitchens 1 and 2 were significantly better than the other kitchens; the CFU/g values were less than $10^{5}$ in all the samples.
Statistical analysis revealed that the variation in $\mathrm{CFU} / \mathrm{g}$ values was not related to the type of meal (soup or main course) or the meal supplier (Fig. 3A and 3B).

The bacterial count values were significantly influenced by the kitchen where the meals were served. Comparison of the kitchens (Fig. 3C) revealed that in kitchens 1 and 2, lower mesophilic aerobic bacterial count values could be measured and the maximum values did not reach the limit value of $10^{5} \mathrm{CFU} / \mathrm{g}$, either.

This result also showed that the level of hygiene in these two kitchens was higher than for the other kitchens. In an earlier investigation, in which 68 kitchens were evaluated for hygienic and sanitary conditions, kitchens No. 1 and 2 were classified as good (see Table 1 and Tóth and Bittsánszky, 2014). It can be concluded that the microbial quality of hot served ready-to-eat meals is significantly influenced by the operational adequacy of the serving kitchen. By this method, it can be concluded that when changes occur in the level of hygiene in a kitchen, the risks increase. If mesophilic aerobic bacterial count values measured in the food served in a kitchen remain high over a long period of time, immediate intervention is necessary. 
Tóth, A. J., Szakmár, K., Dunay, A., Illés, C. B., Bittsánszky, A. (2018). Hygiene assessments of school kitchens based on the microbiological status of served food. Acta Sci. Pol. Technol. Aliment., 17(2), 159-168. http://dx.doi.org/10.17306/J.AFS.2018.0564
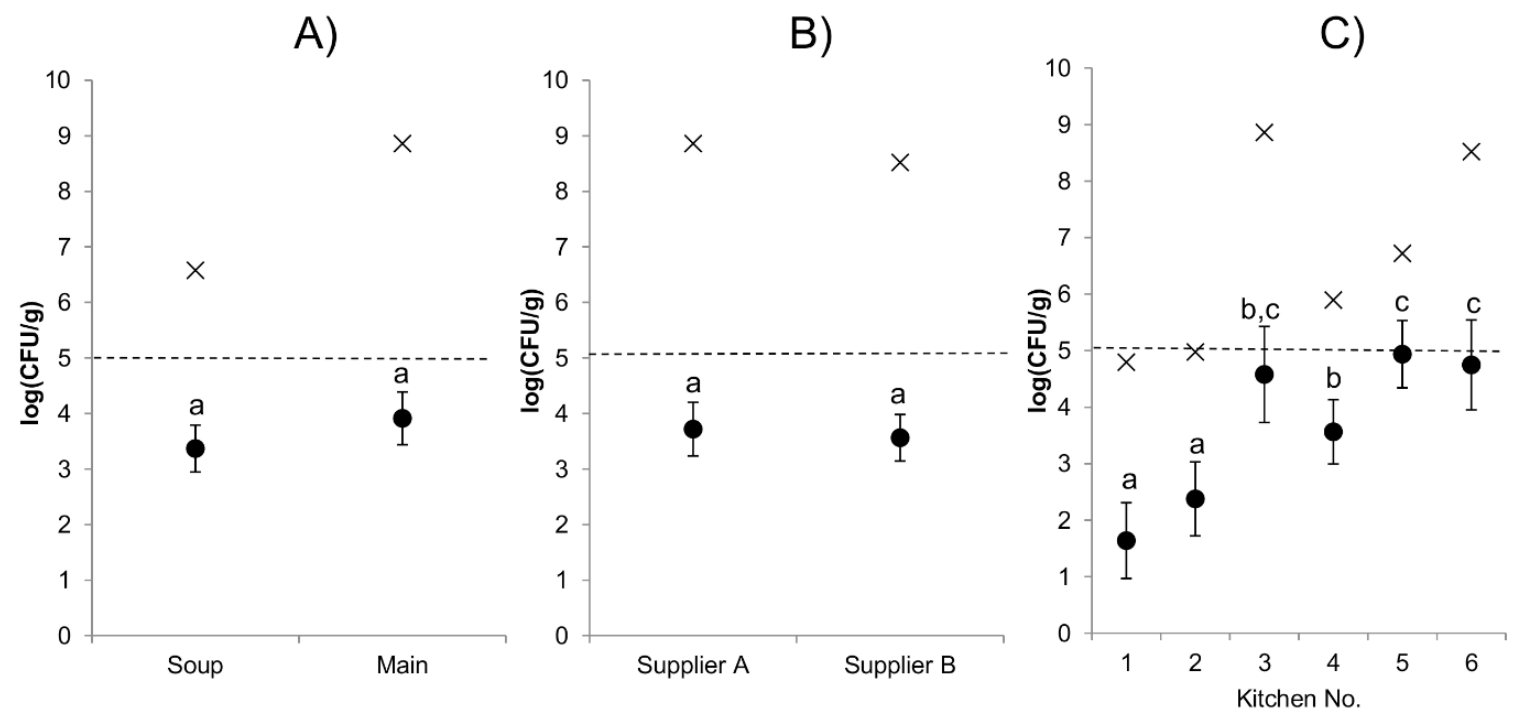

Fig. 3. Mean values of $\log \mathrm{CFU} / \mathrm{g}$ (solid dot \pm standard error of mean) related to mesophilic aerobic bacterial count measurable in the served meals by MicroTester as a function of: meal type (A; $n=90)$, supplier (B; $n=90)$, and type of kitchen $(\mathrm{C} ; n=30)$. Results indicated by different letters are statistically different $(p<0.05$ Student's t-test and ANOVA with Duncan's multiple range test). The highest value measured in a given category is indicated by $\times$. The dashed line indicates $10^{5} \mathrm{CFU} / \mathrm{g}$, generally regarded as limit value

\section{Presence of Enterobacteriaceae}

In the assessment of the meals, the presence or absence of Enterobacteriaceae may be an important viewpoint in terms of hygiene. Enterobacteriaceae are usually killed during heat treatment, therefore their presence in the food after cooking indicates inadequate hygiene. Redox curves referring to the presence of Enterobacteriaceae were recorded in the following cases: kitchen 3 - four main courses $\left(M_{2}, M_{3}, M_{4}, M_{5}\right)$, kitchen 4 - one main course $\left(\mathrm{M}_{4}\right)$, kitchen 5 - three soups $\left(\mathrm{S}_{1}\right.$, $\left.\mathrm{S}_{2}, \mathrm{~S}_{5}\right)$, kitchen 6 - one soup $\left(\mathrm{S}_{2}\right)$ and two main courses $\left(\mathrm{M}_{1}, \mathrm{M}_{4}\right)$.

Measurement of the samples taken from kitchens 1 and 2 did not indicate the presence of Enterobacteriaceae. Data referring to Enterobacteriaceae also confirm that these kitchens operate in good hygienic conditions and that the risk of post-process contamination is much lower.

\section{Hygiene assessment of kitchens}

There are several regulations related to the microbiological status of foodstuffs and specifying limits for certain groups of foods, from a technology and food safety point of view (European Commission, 2005). The hot meals served in school kitchens are regarded as ready-to-eat foods, to which process hygiene standards are not applied. However, although these kinds of foods should meet food safety criteria, the microbial status is tested only when food-borne diseases or other problems occur among consumers. If the raw materials used for the hot meals come from monitored sources, and their storage and use meet the regulations, the mesophilic aerobic bacterial count values measurable in the heat-treated meals are likely to be minimal. However, the procedure by which the ready-made hot food reaches consumers through school kitchens includes several risk points (e.g. delivery; conditions in the kitchens, including the microbiological status of utensils and dishes; the storage time and change of the temperature during storage), which may influence the microbiological status of the meals (Bryan, 1988; Desmarchelier, 2014).

Nowadays, in the school catering sector, it is a common practice that food preparation and consumption are separated in terms of time and space. Every inset procedure between preparation and consumption 
Tóth, A. J., Szakmár, K., Dunay, A., Illés, C. B., Bittsánszky, A. (2018). Hygiene assessments of school kitchens based on the microbiological status of served food. Acta Sci. Pol. Technol. Aliment., 17(2), 159-168. http://dx.doi.org/10.17306/J.AFS.2018.0564

increases the food safety risks. Carrying out the processes of preparation, delivery and receiving the food in an improper manner will result in microorganisms entering the food or its direct environment; favorable conditions for microbes will enable them to grow and multiply (Ayçıçek et al., 2004). Serving readymade meals after an extended period time is a further risk factor. The capacity of the canteens is different for every school; however, it is not possible for any school community to have meals prepared on the spot. In a school kitchen, the meals have to be kept ready for serving for up to $4-5$ hours, taking the time period for delivery into consideration. This task can be duly achieved by operating hot holding units. However, the correct operation of these facilities is crucial, since any technical failure may result in the fast growth of microorganisms, as a consequence of which the quality of the served meal can deteriorate (Bryan, 1988). Numerous studies confirm that most food borne diseases are caused by post-process contamination (Osimani et al., 2013; Pérez-Rodríguez et al., 2008). This affirms the significance of post-preparation controls.

Studies have already been published in which microbiological tests are used for monitoring hygiene in kitchens (Illés et al., 2018; Laranjeiro et al., 2014; Santana et al., 2009; Yoon et al., 2008). In several cases, the size and composition of the microbial communities on work surfaces and utensils used for eating and drinking have been investigated. In addition, there have been several examples of studies regarding the microbial status of samples collected from cold and hot served foods (Ayçıçek et al., 2004; Fang et al., 2003; Garayoa et al., 2014; Osimani et al., 2013; Réglier-Poupet et al., 2005; Rodríguez et al., 2011). Several authors have suggested the introduction of new process hygiene criteria for promoting adequate hygiene practices in the contract catering sector $(\mathrm{Ga}-$ rayoa et al., 2014; Rodríguez et al., 2011). From the results of several samplings, the hygiene level of the kitchens may be evaluated, and the risk of post-process contamination can be determined.

Based on our research, we suggest the regular monitoring and determination of mesophilic aerobic bacterial count in a kitchen qualification system, by which the effectiveness of hygiene practices in a unit can be quantitatively evaluated. The method would be suitable for the indication of changes in hygiene levels. This procedure can be used only in the case of meals that do not require subsequent processing and/ or addition of further ingredients after heat treatment, as additional contamination by subsequently added ingredients can influence the results related to the qualification of kitchens.

Delivering a meal to the consumer is a series of processes and each of the processes is critical. The vast majority of contamination is caused by improper food handling, for which the food handlers are responsible (Egan et al., 2007). Although these monitoring measurements do not give information about the adequacy of procedures, the presence of risks can be revealed. However, although the measurement of other hygiene indicators would be beneficial, it would increase costs and complexity. Mesophilic aerobic bacterial count may be correlated with other hygiene indicators, as already shown in cattle and pig carcasses (Ghafir et al., 2008).

Restaurants/catering kitchens are the final destinations in the food production chain, as the food directly reaches to the consumer from these places and is generally consumed on the spot. Regarding the quality and safety of food, this is the last chance to intervene in the food serving process in order to withdraw defective products. Since the food chain is a series of interconnected flows of goods, services and information, any feedback tends to make the catering service more responsive and efficient (Garcia Martinez et al., 2006; Lehota and Illés, 2005). Quality assurance at this stage could be wide-ranging; however, only rapid methods can be useful and effective at this stage.

The HACCP system guarantees the adequacy of served meals from the point of view of food safety. Its implementation is required in most European countries (European Commission, 2004), and its operation is regularly monitored. By using the HACCP system, food safety hazards, including microbiological risks, can be reduced (Hatakka, 1998). Implementing preventative control is an appropriate way to prevent food contamination. With the above-outlined test method, the effectiveness of these monitoring systems could be evaluated.

The results outlined above may be used to establish the development of a hygiene-based qualification system for kitchens. 
Tóth, A. J., Szakmár, K., Dunay, A., Illés, C. B., Bittsánszky, A. (2018). Hygiene assessments of school kitchens based on the microbiological status of served food. Acta Sci. Pol. Technol. Aliment., 17(2), 159-168. http://dx.doi.org/10.17306/J.AFS.2018.0564

\section{CONCLUSION}

With the present work, we would like to introduce a method that could supplement preventative control, and thus the quality of catering service could be improved. The results show that there is a relationship between the level of hygiene in a kitchen and the microbial quality of the served end-product, and this finding is the basis of the monitoring method. However, although served meals are tested, the ultimate aim of the microbiological measurements is not the determination of food quality. If the microbial count shows an ascending trend, managerial intervention must be conducted. The outlined test method can be used as a tool for risk reduction and to improve the effectiveness of food safety management systems.

\section{REFERENCES}

Ayçıçek, H., Sarimehmetoğlu, B., Çakiroğlu, S. (2004). Assessment of the microbiological quality of meals sampled at the meal serving units of a military hospital in Ankara, Turkey. Food Control, 15(5), 379-384. http:// dx.doi.org/10.1016/S0956-7135(03)00101-4

Baylis, C., Uyttendaele, M., Joosten, H., Davies, A. (2011). The Enterobacteriaceae and their significance to the food industry (pp. 9-12). ILSI Europe Report Series. Brussels: ILSI Eur. Int. Life Sci. Inst.

Bibek, R., Bhunia, A. (2014). Fundamental food microbiology. $5^{\text {th }}$ ed. Boca Raton, FL: CRC Press.

Bonell, C., Wells, H., Harden, A., Jamal, F., Fletcher, A., Thomas, J., ..., Moore, L. (2013). The effects on student health of interventions modifying the school environment: systematic review. J. Epidemiol. Comm. Health, 67(8), 677-681. http://dx.doi.org/10.1136/jech-2012202247

Brasca, M., Morandi, S., Lodi, R., Tamburini, A. (2007). Redox potential to discriminate among species of lactic acid bacteria. J. Appl. Microbiol., 103(5), 1516-1524. http://dx.doi.org/10.1111/j.1365-2672.2007.03392.x

Bryan, F. L. (1988). Risks of practices, procedures and processes that lead to outbreaks of foodborne diseases. J. Food. Prot., 51(8), 663-673.

Cohen, J. F. W., Richardson, S., Parker, E., Catalano, P. J., Rimm, E. B. (2014). Impact of the new U.S. Department of Agriculture School Meal Standards on food selection, consumption, and waste. Am. J. Prev. Med., 46(4), 388394. http://dx.doi.org/10.1016/j.amepre.2013.11.013
Cohen, J. F. W., Smit, L. A., Parker, E., Austin, S. B., Frazier, A. L., Economos, C. D., Rimm, E. B. (2012). Longterm impact of a chef on school lunch consumption: Findings from a 2-year pilot study in Boston middle schools. J. Acad. Nutr. Diet., 112(6), 927-933. http:// dx.doi.org/10.1016/j.jand.2012.01.015

Desmarchelier, P. (2014). Safe handling of food in homes and food services. In: Y. Motarjemi, H. Lelieveld (Eds.), Food safety management (pp. 821-844). Elsevier. http:// dx.doi.org/10.1016/B978-0-12-381504-0.00030-5

Egan, M. B., Raats, M. M., Grubb, S. M., Eves, A., Lumbers, M. L., Dean, M. S., Adams, M. R. (2007). A review of food safety and food hygiene training studies in the commercial sector. Food Control, 18(10), 1180-1190. http://dx.doi.org/10.1016/j.foodcont.2006.08.001

Erdősi, O., Szakmár, K., Reichart, O., Székely-Körmöczy, P., Laczay, P. (2012). Application of the redox potential measurement based rapid method in the microbial hygienic control. Acta Aliment., 41(1), 45-55. http:// dx.doi.org/10.1556/AAlim.2011.0005

European Commission (2004). Regulation (EC) no 852/2004 of the European Parliament and of the Council of 29 April 2004 on the Hygiene of Foodstuffs. OJ L 139/47, 1-54.

European Commission (2005). Commission Regulation (EC) no 2073/2005 of 15 November 2005 on Microbiological Criteria for Foodstuffs. OJ L 338/48, 1-26.

Fang, T. J., Wei, Q. K., Liao, C. W., Hung, M. J., Wang, T. H. (2003). Microbiological quality of $18^{\circ} \mathrm{C}$ ready-toeat food products sold in Taiwan. Int. J. Food Microbiol., 80(3), 241-250. http://dx.doi.org/10.1016/S01681605(02)00172-1

Garayoa, R., Díez-Leturia, M., Bes-Rastrollo, M., García-Jalón, I., Vitas, A. I. (2014). Catering services and HACCP: Temperature assessment and surface hygiene control before and after audits and a specific training session. Food Control, 43, 193-198. http://dx.doi.org/ 10.1016/j.foodcont.2014.03.015

Garcia Martinez, M., Poole, N., Skinner, C., Illés, Cs. B., Lehota, J. (2006). Food safety performance in European union accession countries: Benchmarking the fresh produce import sector in Hungary. Agribusiness, 22(1), 69-89. http://dx.doi.org/10.1002/agr.20073

Ghafir, Y., Dierick, K., Zutter, L. D. E. (2008). Hygiene indicator microorganisms for selected pathogens on beef, pork, and poultry meats in Belgium. J. Food Prot., 71(1), 35-45.

Hatakka, M. (0998). Microbiological quality of hot meals served by airlines. J. Food Prot., 61(8), 1052-1056. 
Tóth, A. J., Szakmár, K., Dunay, A., Illés, C. B., Bittsánszky, A. (2018). Hygiene assessments of school kitchens based on the microbiological status of served food. Acta Sci. Pol. Technol. Aliment., 17(2), 159-168. http://dx.doi.org/10.17306/J.AFS.2018.0564

Health Protection Agency of United Kingdom (2009). Guidelines for Assessing the Microbiological Safety of Ready-to-Eat Foods Placed on the Market, Health Protection Agency, London.

Ignatova, M., Prévost, H., Leguerinel, I., Guillou, S. (2010). Growth and reducing capacity of Listeria monocytogenes under different initial redox potential. J. Appl. Microbiol., 108(1), 256-265. http://dx.doi.org/10.1111/ j.1365-2672.2009.04426.x

Illés, B. C., Tóth, A. J., Dunay, A., Lehota, J., Bittsánszky, A. (2018). Evaluation of food safety knowledge and microbial status of food contact surfaces in schools. J. Food Safety, 38, JFS12480. http://dx.doi.org/10.1111/ jfs. 12480

ISO 4833:2003. Microbiology of food and animal feeding stuffs - Horizontal method for the enumeration of microorganisms - Colony-count technique at 30 degrees C.

Jay, J. M., Loessner, M. J., Golden, D. A. (2005). Modern food microbiology. $7^{\text {th }}$ ed. New York: Springer.

Laranjeiro, C., Santos, C., Alves, B., Ferreira, A., Figueired, J. P. (2014). Microbiological parameters of surfaces in school canteens. In: P. M. Arezes (Ed.), Occupational safety and hygiene II - Selected extended and revised contributions from the International Symposium Occupational Safety and Hygiene. Guimarães, Portugal, 13-14 February 2014 (pp. 355-360). Boca Raton: CRC Press, Taylor and Francis Group.

Lehota, J., Illés, B. Cs. (2005). Benchmarking of the United Kingdom's and Hungary's fresh produce import supply chain focusing on food safety and quality. Societ. Econ., 27(3), 355-364. http://dx.doi.org/10.1556/SocEc.27.2005.3.8

Osimani, A., Aquilanti, L., Tavoletti, S., Clementi, F. (2013). Evaluation of the HACCP System in a University Canteen: Microbiological monitoring and internal auditing as verification tools. Int. J. Environ. Res. Public. Health, 10(4), 1572-1585. http://dx.doi.org/10.3390/ ijerph 10041572

Pérez-Rodríguez, F., Valero, A., Carrasco, E., García, R. M., Zurera, G. (2008). Understanding and modelling bacterial transfer to foods: a review. Trends Food. Sci. Technol., 19(3), 131-144. http://dx.doi.org/10.1016/j. tifs.2007.08.003

Réglier-Poupet, H., Parain, C., Beauvais, R., Descamps, P., Gillet, H., Le Peron, J. Y., ..., Ferroni A. (2005).
Evaluation of the quality of hospital food from the kitchen to the patient. J. Hosp. Infect., 59(2), 131-137. http:// dx.doi.org/10.1016/j.jhin.2004.07.023

Reichart, O., Szakmár, K., Jozwiak, A., Felföldi, J., Baranyai, J. (2007). Redox potential measurement as a rapid method for microbiological testing and its validation for coliform determination. Int. J. Food Microbiol., 114(2), 143-148. http://dx.doi.org/10.1016/j.ijfoodmicro.2006.08.016

Rodríguez, M., Valero, A., Posada-Izquierdo, G. D., Carrasco, E., Zurera, G. (2011). Evaluation of food handler practices and microbiological status of ready-to-eat foods in long-term care facilities in the Andalusia region of Spain. J. Food. Prot., 74(9), 1504-1512. http://dx.doi. org/10.4315/0362-028X.JFP-10-468

Santana, N. G., Almeida, R. C., Ferreira, J. S., Almeida, P. F. (2009). microbiological quality and safety of meals served to children and adoption of good manufacturing practices in public school catering in Brazil. Food Control, 20(3), 255-261. http://dx.doi.org/10.1016/j.foodcont.2008.05.004

Tachon, S., Brandsma, J. B., Yvon, M. (2010). NoxE NADH oxidase and the electron transport chain are responsible for the ability of Lactococcus lactis to decrease the redox potential of milk. Appl. Environ. Microbiol., 76(5), 1311-1319. http://dx.doi.org/10.1128/AEM.02120-09

Tortorello, M. L. (2003). Indicator organisms for safety and quality - uses and methods for detection: Minireview. J. AOAC Int., 86(6), 1208-1217.

Tóth, A. J., Bittsánszky, A. (2014). A comparison of hygiene standards of serving and cooking kitchens in schools in Hungary. Food Control, 46, 520-524. http://dx.doi. org/10.1016/j.foodcont.2014.06.019

Vieux, F., Dubois, C., Allegre, L., Mandon, L., Ciantar, L., Darmon, N. (2013). Dietary standards for school catering in France: Serving moderate quantities to improve dietary quality without increasing the food-related cost of meals. J. Nutr. Educ. Behav., 45(6), 533-539. http:// dx.doi.org/10.1016/j.jneb.2013.02.004

Yoon, Y., Kim, S.-R., Kang, D.-H., Shim, W.-B., Seo, E., Chung, D.-H. (2008). Microbial assessment in school food services and recommendations for food safety improvement. J. Food Sci., 73(6), 304-313. http://dx.doi. org/10.1111/j.1750-3841.2008.00828.x 